\title{
Stress-strain response of sheared wheat granular material stored in silos using triaxial compression tests**
}

\author{
Changnv Zeng ${ }^{1}, \mathrm{He} \mathrm{Gu}^{1}$, and Yuke Wang ${ }^{2,3 *}$ \\ ${ }^{1}$ College of Civil Engineering and Architecture, Henan University of Technology, Zhengzhou, 450001, China \\ ${ }^{2}$ College of Water Conservancy Engineering, Zhengzhou University, Zhengzhou, 450001, China \\ ${ }^{3}$ Collaborative Innovation Center of Water Conservancy and Transportation Infrastructure Safety Protection, Henan Province, \\ Zhengzhou University, Zhengzhou, 450001, China
}

Received May 17, 2019; accepted January 3, 2020

\begin{abstract}
A b stract. Wheat granular material stored in silos usually suffers shearing loads, which induces complex stress-strain response during the silo filling and discharging process. In order to guarantee the safe storage of these granular materials, it is necessary to investigate the shearing behaviour of wheat granular material in silos. In this paper, a series of triaxial tests were conducted on wheat granular material by using a modified double cell triaxial system. The stress-strain responses including the volumetric strain behaviour were examined considering the effect of the initial void ratio, confining pressure and shearing velocity. Different shearing states were discussed to obtain their strength parameters in various conditions. The results show that the shearing characteristics of wheat granular material are influenced by the shearing velocity. The friction angles increase with the decreasing void ratio at different states. The final volumetric strain decreases with increasing confining pressure, and the dilation is diminished. The dilatancy behaviour was quantitatively evaluated based on Row's theory for wheat granular material. The stress-strain relationship of wheat granular material was then determined.
\end{abstract}

Keywords: wheat granular, void ratio, confining pressure, shearing velocity, strength, dilatancy

\section{INTRODUCTION}

Wheat granular materials are usually stored in silos, which are used in many industries including chemical, agriculture, mining, food processing, and electric power generation (Rotter et al., 2009; Dogangun et al., 2009;

\footnotetext{
*Corresponding author e-mail: ykewang@163.com

**This work was substantially supported by the Plan for Youth Core Teachers of Henan University of Technology (2015004), the Provincial Key Laboratory for Grain and Oil Storage Facility \& Safety, Henan University of Technology (2016KF-B03) (2016-2019), Key Scientific Research Project Plan of Colleges and Universities in Henan Province (19A560009; 20A56002) (2019-2021), and China Postdoctoral Science Foundation (2019M662533) (2019-2021).
}

Zeng et al., 2019a). The load from the stored material is a critical point in the practical design of a silo, and one, which frequently induces failure in silos (Carson, 2001; Ayuga et al., 2005; Carson et al., 2015). There still exists some uncertainty in the selection of the appropriate mechanical parameters for technicians. It has been deduced that mass flow discharge pressures may be caused by the dilatancy of dense sheared material in silos (Zhang and Britton, 2003). Therefore, it is of great importance to achieve a better understanding of the shear behaviour of wheat granular material stored in silos.

As the density, flow and friction properties of agricultural materials vary widely, the loads applied on a silo are complex considering that the conditions of storage vary (Nielsen, 1977; Puri, 2002; Moya et al., 2002; Ramirez et al., 2009; Stasiak et al., 2010; Liu et al., 2014; Horabik and Molenda, 2017). The traditional triaxial apparatus cannot simulate the complex condition in actual engineering (Wang et al., 2017, 2018, 2019). The numerical method may accurately model the complex shear behaviour of stored wheat granular material (Ramirez et al., 2010; Ruiz et al., 2012; Rotter et al., 1998; Ayuga et al., 2001; Guaita et al., 2003; Zhao et al., 2013; Zhang et al., 2014; Kobyłka et al., 2017). In these cases, the stress-strain behaviour is particularly of the most major concern (Goodey et al., 2017).

The conventional triaxial compression apparatus was used to obtain the compressibility and frictional coefficients, strength parameters, and constitutive model of the agricultural materials (Thompson et al., 1983; Zhang et al., 1986; Tripodi et al., 1994; Turner et al., 2016). Other given parameters, such as the internal friction angle, elastic

(C) 2020 Institute of Agrophysics, Polish Academy of Sciences 
parameters and dilatancy angle, were also obtained from the common triaxial apparatus or customized triaxial apparatus (Britton and Moysey, 1986; Hardin et al., 1990; Moya et al., 2013; Zeng et al., 2019b). While the volume change behaviour is still poorly understood, it is an essential factor used to describe the stress-strain behaviour of material. The wheat granular material stored in silos has very different properties from those of saturated soil, which is in a nearly dry condition. The conventional triaxial compression apparatus cannot be used to measure the volume change during shearing.

Considering the problems mentioned above, the conventional triaxial system was modified to be used in testing granular material. A series of triaxial tests were carried out to investigate the volumetric properties and strength response. The effects of the void ratio, confining pressure and shearing velocity on the stress-strain response were examined. The purpose of this investigation was to better understand the effect of different parameters on the triaxial behaviour of wheat.
EXPERIMENTAL PROCEDURE AND MATERIALS

The triaxial system is commonly used in geotechnical engineering. The traditional method for measuring the sample volume change which is used in the triaxial testing of saturated soils involves measuring the pore fluid that leaves or enters the sample. This is no longer sufficient in an unsaturated soil, as water volume and sample volume are not linked. In order to overcome the limitations of using a traditional triaxial cell, different double cell triaxial systems (Wheeler et al., 1988; Yin et al., 2003) were enhanced based on the work of Bishop and Donald (1961). These apparatuses were developed especially for measuring the volume changes of unsaturated soil specimens. Analogous to soil, the grains stored in silos behave like unsaturated or dry granular soil. Therefore, the double cell system may be used to test granular materials. In order to obtain such measurements, the double cell system was modified based on the traditional common triaxial system.

The biggest difference between the modified and traditional triaxial system is the double cell, which consists of a double cell connected to the volume measure transducer (Fig. 1). Specifically, the double cell was formed by top
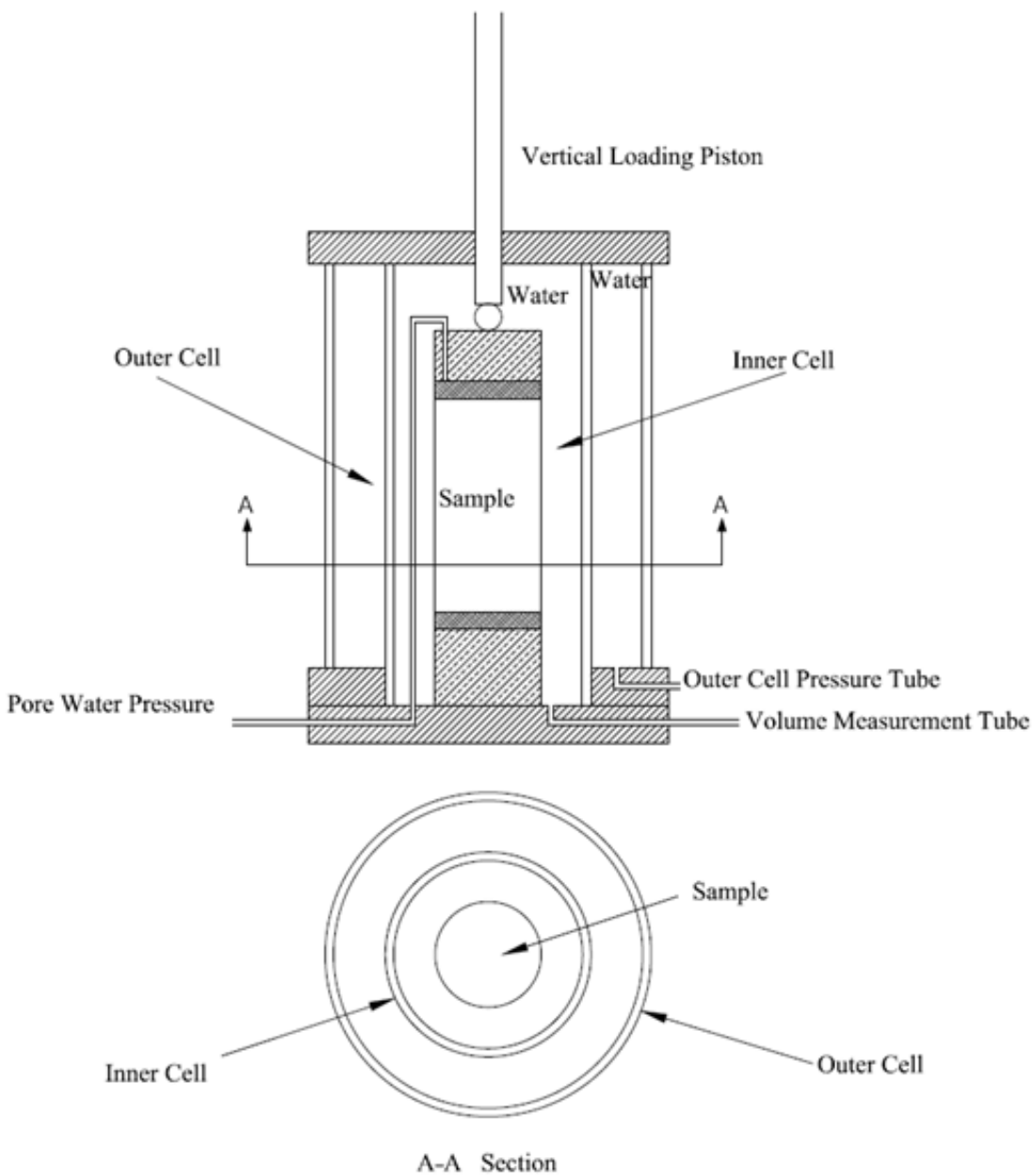

Fig. 1. Scheme of the modified double wall tri-axial system. 
and bottom flanges, fixed and sealed to a double transparent plexiglass cylinder by screws. Both the inner and the outer container are connected with top and bottom flanges. The apparatus could be dismantled to allow for the installation and removal of specimens.

The outer cell has an internal diameter of $160 \mathrm{~mm}$, a height of $250 \mathrm{~mm}$, and a wall thickness of $5 \mathrm{~mm}$ (Fig. 1). The internal diameter, height, and wall thickness of the inner cell is 100,250 , and $5 \mathrm{~mm}$, respectively. The standard size for a specimen is a diameter of $61.8 \mathrm{~mm}$ and a height of $125 \mathrm{~mm}$. The inner container and the outer cell were both filled with de-aired water during the tests. There was a volume measurement tube connected with the inner cell. The cell pressure was applied using water in the outer container, while the vertical applied load system was the same as that used in the common triaxial system.

In order to monitor the sample volume change, we referred to the readings of the volume transducer connected to the inner cell. The water volume contained in the inner cell was the initial water volume. The volume changes of the specimen were measured by monitoring the water flowing out of (or into) the inner cell using a volume transducer.

Saturated silt soil was used to verify the system. The basic properties of the silt soil were the specific gravity $G_{\mathrm{s}}=2.69$, plastic index $I_{\mathrm{p}}=6.8$, and initial water content $w_{\mathrm{n}}=24.6 \%$, the initial void ratio was 0.852 . The specimen was saturated, consolidated and sheared, respectively.

There were two methods used to verify the volume measurement. Method A involved measuring the volume of water coming out (or into) of the saturated specimen, while for Method B the water volume change of the inner cell was measured. The results of volume changes with axial strain were obtained at a cell pressure of $200 \mathrm{kPa}$ with a constant axial strain rate of $1 \mathrm{~mm} \mathrm{~min}^{-1}$ and all drainage valves opened (Fig. 2a, b). The curves of volumetric strain obtained using the two methods were very similar. The volume measured using the inner cell (Method B) was slightly smaller than that measured using Method A. This error may be acceptable for the tests.

In order to study the mechanical properties of wheat grain, it must be taken into account that a kernel of grain is not an inert material like most particles of soil. A kernel of grain is composed of a large number of different types of cells, which respond to the process of osmosis when exposed to moisture. In the lower moisture content range (below $16.0 \%$ ), the grains are hard, brittle and have a smooth surface. The wheat used for the investigations was a winter wheat, grown in Henan Province, China. The following physical properties were described.

1. Particle shape and particle size distribution curve

The particle shapes were quantified by the lengths of the major and minor axes (Fig. 3). The average major axis (named as $a$ ) and minor axis (named as the average of $b_{1}$ and $b_{2}$ ) of twenty grains was 6.05 and $3.48 \mathrm{~mm}$, respectively. Consequently, the ratio of $a / b$ ranges from 1.67 to 1.86 .

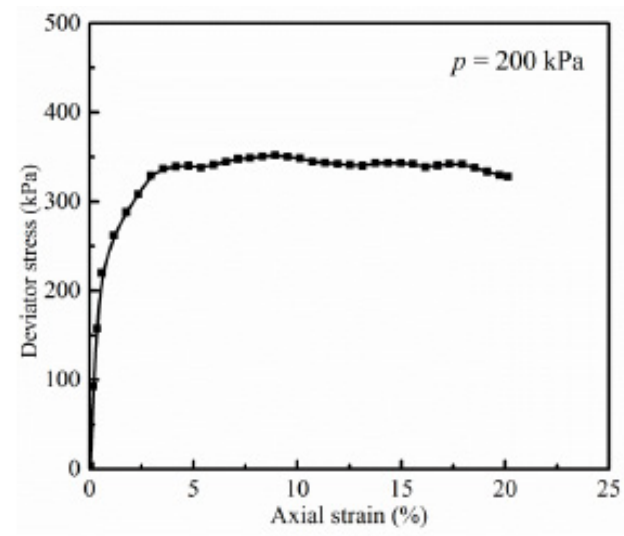

(a)

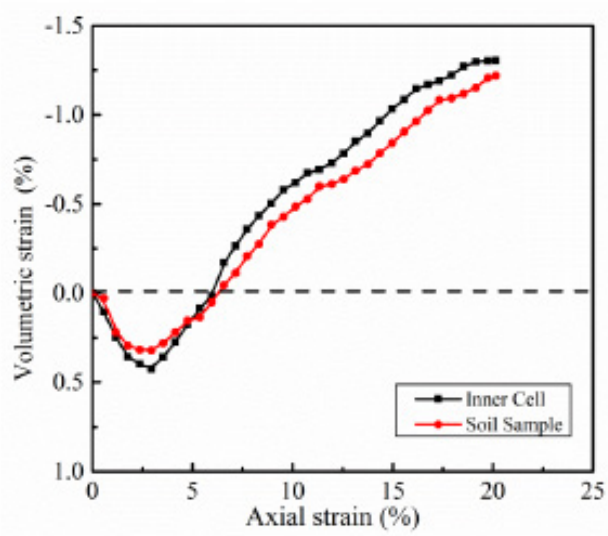

(b)

Fig. 2. (a) Deviator stress versus the axial strain under pressure $\mathrm{p}=200 \mathrm{kPa}$; and (b) Volumetric strains measured by soil sample (Method A) and inner cell (Method B).

In terms of geotechnical engineering, the grading curve was a graphical representation of the particle-size distribution and was therefore useful in itself as a means of describing the soil. By referring to soil, the particle-size distribution tests for the wheat granular material were conducted. The size of the cereal particles that constituted the wheat granular material were large enough to be inspected with the naked eye (Fig. 3). They constituted the coarse fractions of the wheat granular material. In the case of the coarse granular material, the usual process is a sieve analysis. It has been found that the size of most of the grains in the aggregate of wheat particles is within the limits given for only one fraction. The particle-size distribution curve was plotted as a semilogarithmic curve (Fig. 4). The general slope and shape of the distribution curve can be described by means of the coefficient of uniformity $\left(C_{u}\right)$ and the coefficient of gradation $\left(C_{c}\right)$, which may be calculated from Eqs (1) and (2), respectively. The results of the $a / b$ ratio and particle-size distribution curve showed that the wheat was very uniform:

$$
C_{u}=\frac{D_{60}}{D_{10}}
$$




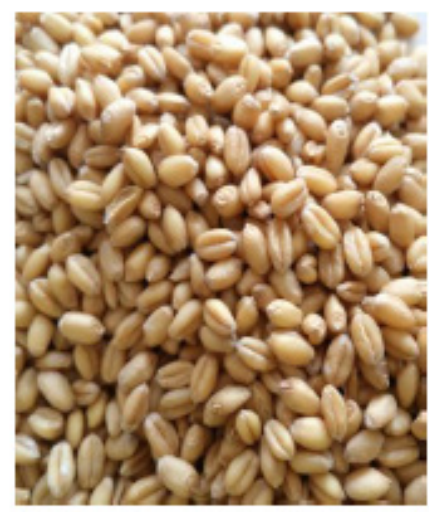

(a)
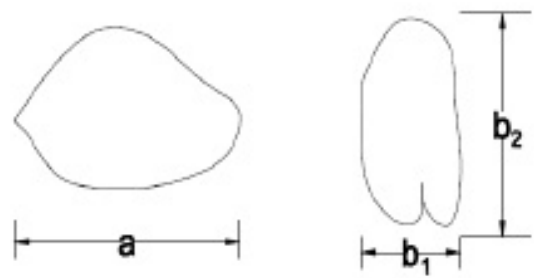

(b)

Fig. 3. Samples used in this paper (a); size of wheat grain (b).

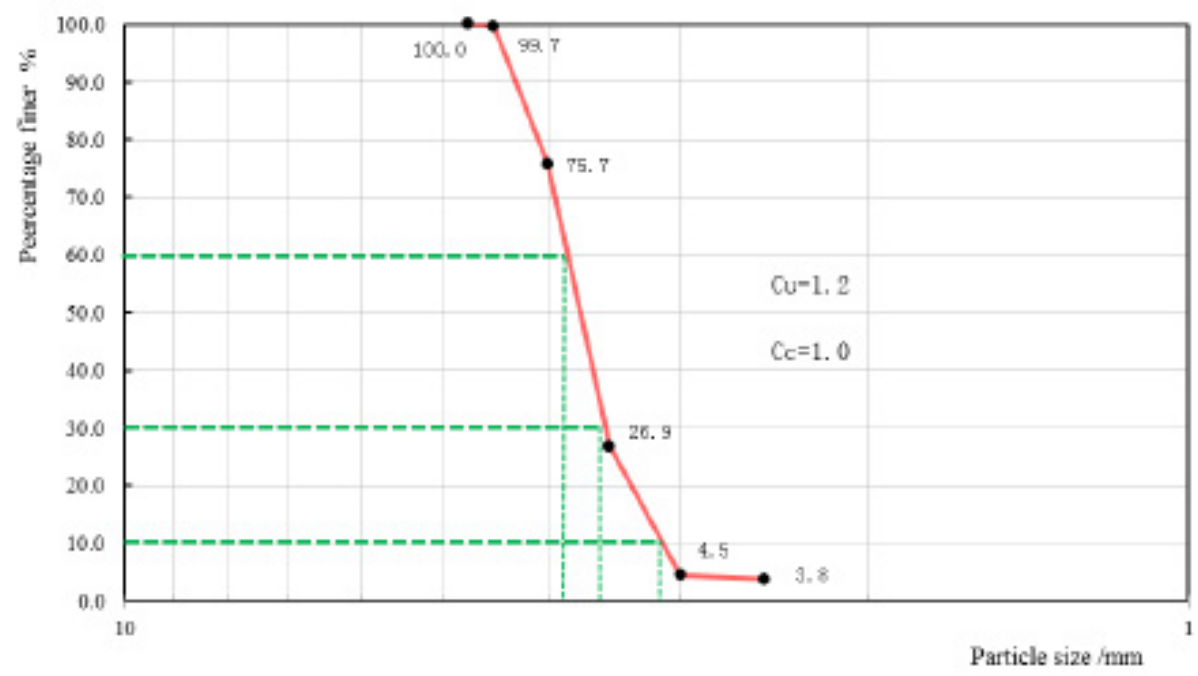

Fig. 4. Particle size distribution curve.

$$
C_{c}=\frac{\left(D_{30}\right)^{2}}{D_{60} D_{10}},
$$

where: $D_{60}$ is the diameter of the wheat particles at which $60 \%$ of the particles are smaller, $D_{30}$ is the diameter of the wheat particles at which $30 \%$ of the particles are smaller, and $D_{10}$ is the diameter of the wheat particles at which $10 \%$ of the particles are smaller.

\section{Bulk density tests}

A mass of wheat grain consists of solid kernels of grain, which contain water in their cells, and void spaces filled with air. Changes in their packing pattern will further affect the bulk density and shear strength.

The granular mass is commonly considered to consist of a network of solid particles, enclosing voids of varying sizes. The void ratio of the samples is described by Eq. (3).

$$
e=\frac{\rho_{s}-\rho}{\rho}=\frac{G_{s} \rho_{w}}{\rho}-1
$$

where: the specific gravity of wheat $G_{s}$ is 1.31 , which is obtained by using the pycnometer method (Zeng et al., 2019), $\rho$ is the density of the wheat mass, $e$ is the void ratio, $\rho_{w}=1 \mathrm{~g} \mathrm{~cm}^{-3}$. It should be noted that only the void ratio of the wheat, which was usually present in the silos is discussed, particularly the medium dense to dense wheat discussed in this paper.

\section{Moisture content measurement}

In the study of wheat grain, the condition of free water is supposed never to encounter in the pore spaces of the grain mass. The moisture content in the wheat kernel is obtained.

According to ASAE S352.2 APR1988 (R2017), $10 \mathrm{~g}$ of a representative wheat sample was placed in a dish, which was dried at $130^{\circ} \mathrm{C}$ in an oven for at least $19 \mathrm{~h}$. The percentage of moisture (wet basis) was calculated by dividing the loss in weight due to heating by the weight of the original sample and multiplying by 100 . In this paper, the moisture content (wet basis) was $10.6 \%$ (w.b.), the moisture content (dry basis) of test sample was 11.9\% (d.b.). 
A total of 21 triaxial compression tests were performed using the modified triaxial apparatus. The strain-controlled tests were conducted with constant confining pressure during each test. Cylindrical specimens were first consolidated under three confining pressures $p$ of 50,100 , and $200 \mathrm{kPa}$ and sheared at different shearing velocities $v$ of $0.05,0.1$, $0.2,0.5$, and $1 \mathrm{~mm} \mathrm{~min}^{-1}$. The initial void ratio $e_{0}$ changed by $0.465,0.525$, and 0.566 . The detailed descriptions are shown in Table 1 . When the axial strain reaches nearly $20 \%$, the tests should be terminated.

Specimens were prepared by pouring a calculated mass of wheat into the mould, by addition with a spoon for loose samples, five times for each specimen, each time the material was tamped using a steel rammer for dense samples but without destroying the grain particles. The density of the wheat at a specified initial void ratio may be calculated using Eq. (3), thus the calculated mass of wheat may be obtained.

During the tests, the axial load, axial displacement, volume change and cell pressure were measured using different types of transducers, including load cell, linear variable differential transducers (LVDT) and volume change transducers. Both the LVDT for the axial displacement measurement and the load cell were mounted outside the triaxial chamber. All data were acquired automatically by a computer-controlled data acquisition system.

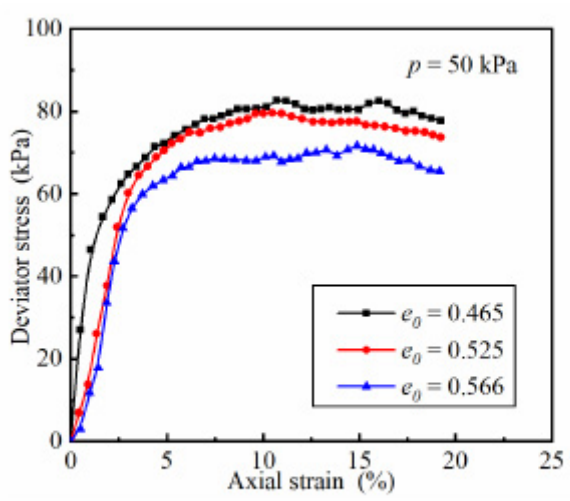

(a)

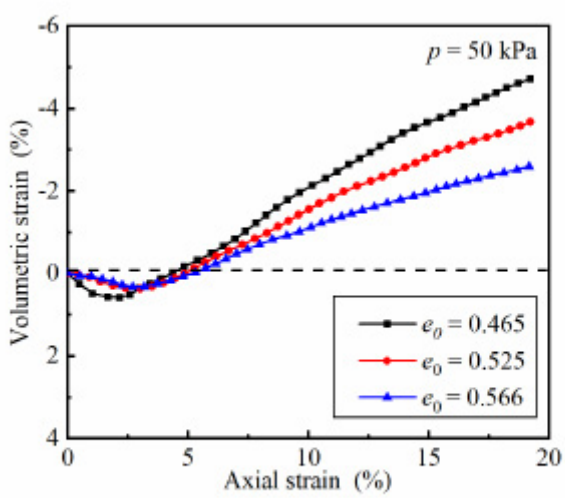

(b)

Fig. 5. Stress-strain response at $50 \mathrm{kPa}$ : (a) stress-strain curve; (b) volumetric strain-strain curve.
Table 1. Test scheme

\begin{tabular}{lccc}
\hline Test ID. & $\begin{array}{c}\text { Shearing } \\
\text { velocity } \\
\left(\mathrm{mm} \mathrm{min}^{-1}\right)\end{array}$ & $\begin{array}{c}\text { Confining } \\
\text { pressure } \\
p(\mathrm{kPa})\end{array}$ & $\begin{array}{c}\text { Void } \\
\text { ratio } e_{0}\end{array}$ \\
\hline A1(A2,A3) & 0.05 & $50,100,200$ & 0.465 \\
B1(B2,B3) & 0.1 & $50,100,200$ & 0.465 \\
C1(C2,C3) & 0.2 & $50,100,200$ & 0.465 \\
C4(C5,C6) & 0.2 & $50,100,200$ & 0.525 \\
C7(C8,C9) & 0.2 & $50,100,200$ & 0.566 \\
D1(D2,D3) & 0.5 & $50,100,200$ & 0.465 \\
E1(E2,E3) & 1.0 & $50,100,200$ & 0.465 \\
\hline
\end{tabular}

\section{EXPERIMENTAL RESULTS}

The typical experimental results are presented for wheat with different void ratios under a confining pressure of $50 \mathrm{kPa}$ (Fig. 5). The development of axial deviator stresses and volumetric strains versus axial strain is presented (Fig. 5a). When larger strains are applied, the deviator stress increases quickly at the value of axial strain of $2.5 \%$ and

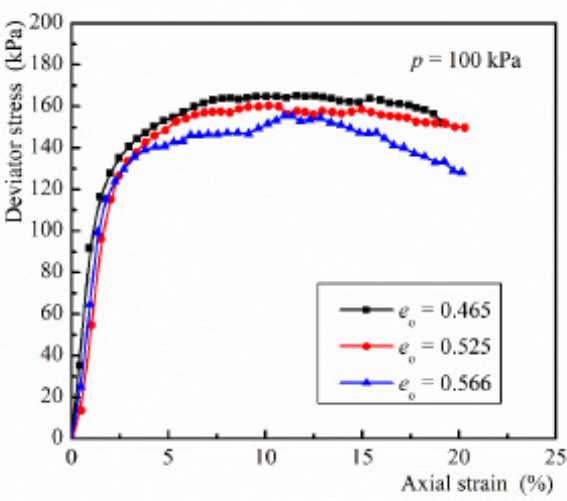

(a)

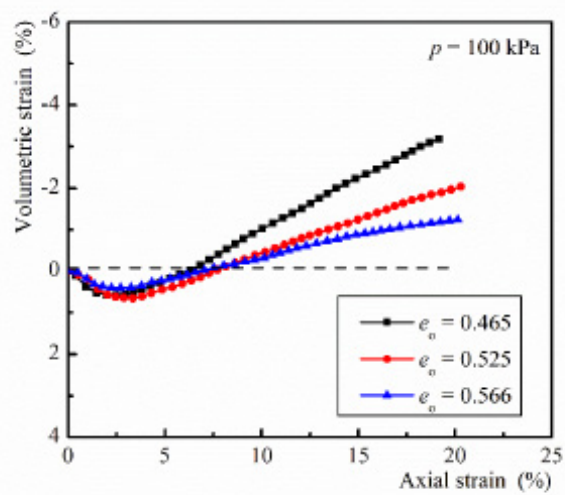

(b)

Fig. 6. Stress-strain response at $100 \mathrm{kPa}$ : (a) stress-strain curve; (b) volumetric strain-strain curve. 


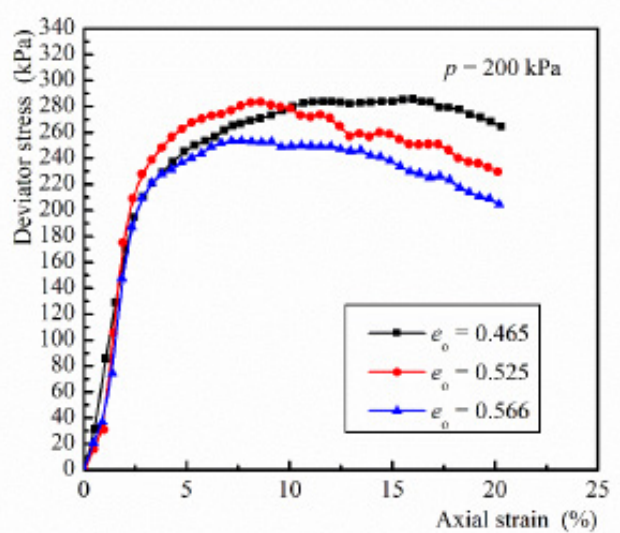

(a)

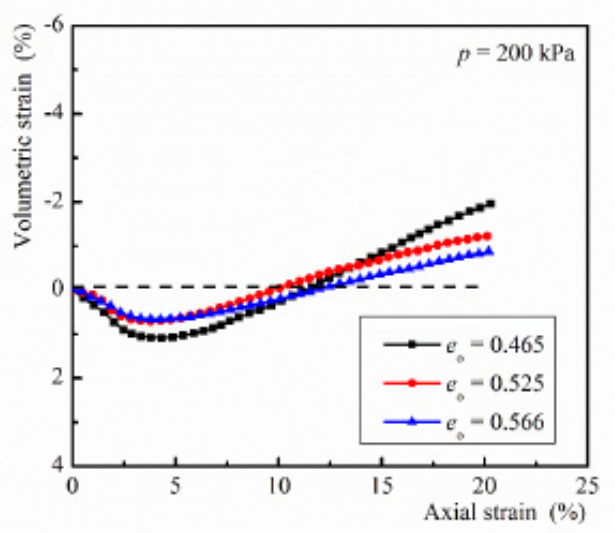

(b)

Fig. 7. Stress-strain response at $200 \mathrm{kPa}$ : a) stress-strain curve, b) volumetric strain-strain curve.

then tends to reach a steady value. The maximum deviator stress at the plateau strain increases with the decreasing void ratio, and the value ranges from 5 to $10 \%$.

Moreover, a similar dilative pattern of wheat is developed with increasing axial strain (Fig. 5b). During the shearing procedure, the increasing axial strain or deviator stress changes the dilation pattern from the initial contraction to dilation. The initial contraction is marginal, an axial strain of only $1-2 \%$ occurs, and it is closely followed by dilation at a larger axial strain (greater than $3 \%$ axial strain).

The effects of the void ratio, confining pressure and shearing velocity on the stress-strain response were also examined. The shear strength and volumetric strain decreases slightly with the increasing void ratio value under a fixed shearing velocity (Figs 5-7). It showed that with the initial void ratio decreasing from 0.566 to 0.465 , the negative volumetric strain increased significantly from -2.6 to $-4.7 \%$ at the end of tests under a confining pressure of $50 \mathrm{kPa}$. For samples with the same initial void ratio, the final volumetric strain decreases with each increase in confining pressure, and then the dilation is diminished (Fig. 8),

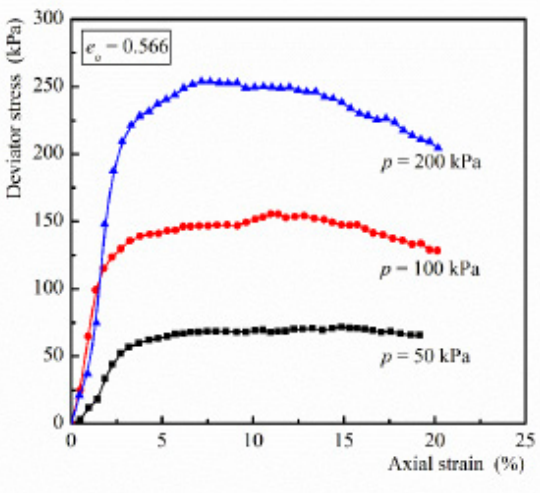

(a)

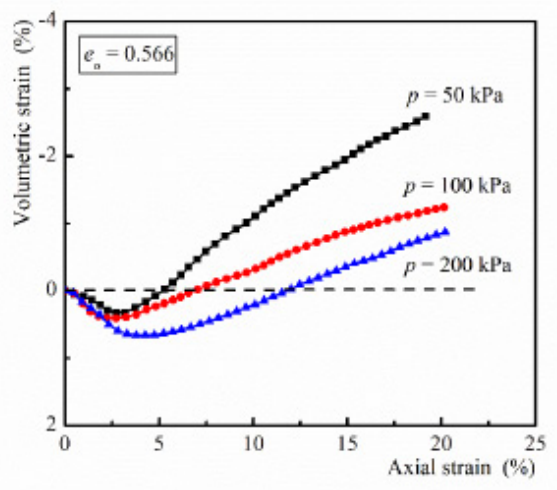

(b)

Fig. 8. Effect of confining pressure on stress-strain response at $0.2 \mathrm{~mm} \mathrm{~min}^{-1}$.

In order to discuss the shear resistance of wheat, the peak strength and the corresponding internal friction angle are discussed. The peak strength was evaluated using the maximum value of $q / p$, where $p$ represents the confining pressure, $q$ represents the deviator stress defined as $q=$ $\left(\sigma_{1}-\sigma_{3}\right) / 2$. The maximum $q / p$ value ranges from 1.268 to 1.655. Based on the experimental results, the ratio of $q / p$ is affected by the void ratio, confining pressure and shearing velocities. The relationships between $q / p$, initial void ratio $e_{0}$ and shearing velocity may be elucidated (Fig. 9a, b). It may be observed that the strength value is approximately the same under different initial void ratio and shearing velocity values when $p=50 \mathrm{kPa}$ and $p=100 \mathrm{kPa}$, while the value of $q / p$ is a bit lower under $p=200 \mathrm{kPa}$. It may be concluded that the effect of the material structure becomes less important and the monotonic shear strength ratio is lower at higher confining pressure values.

The Mohr-Coulomb failure theory was used to obtain various shear strength values to define the failure envelopes. The slope of the curve provides the angle of internal friction, which shows the peak state corresponding to the 


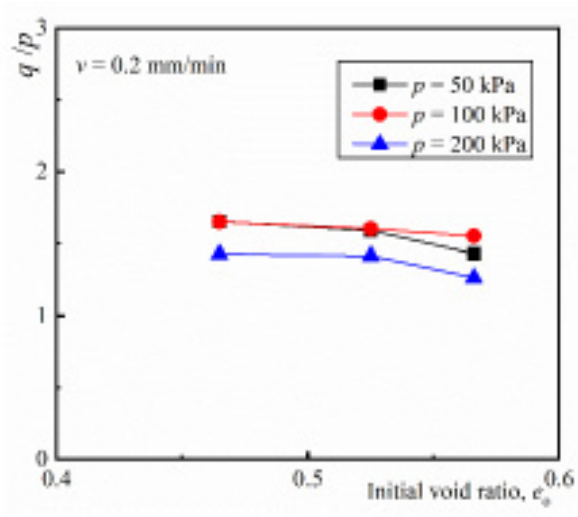

(a)

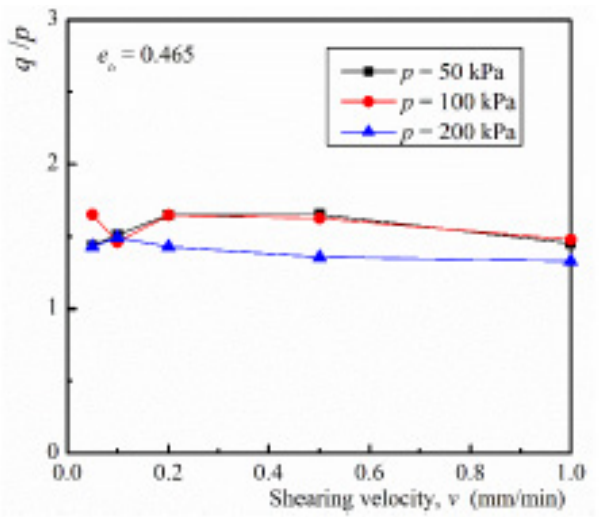

(b)

Fig. 9. The relationships between: a) $q / p$ and initial void ratio $e_{\mathrm{o}}$ for $v=0.2 \mathrm{~mm} \mathrm{~min}^{-1}$; b) $q / p$ and shearing velocity $v$ for $e_{\mathrm{o}}=0.465$.

shear resistance (Fig. 10). The intersection point between that curve and the y-axis provides the apparent cohesion value.

The internal friction angle of wheat in this paper ranges from 25.2 to $26.9^{\circ}$ in Table 2 , which were similar to the values reported in other publications and technical standards (Moya et al., 2006; Zeng et al., 2019b; ACI 313-97; BS EN1991-4-2006; GB 50077-2017). The internal friction angle is affected by both the shearing velocity and void ratio. The internal friction angle shows a slight decrease

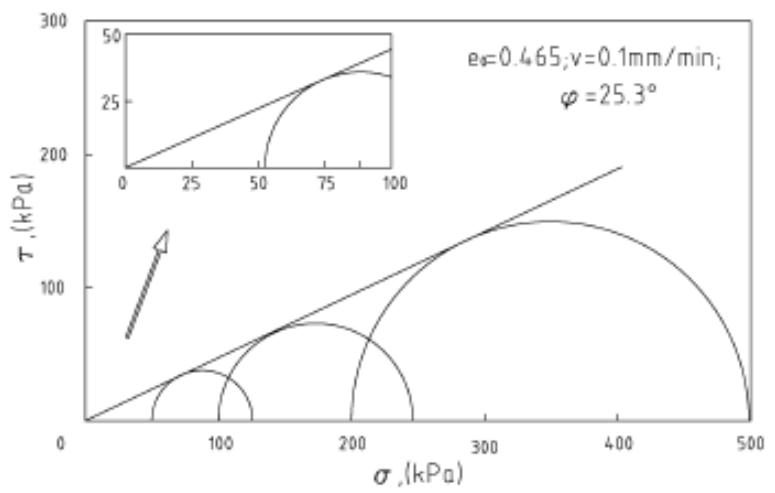

Fig. 10. Mohr-Coulomb strength envelopes obtained for wheat.

Table 2. Values obtained for the internal friction angle from triaxial test

\begin{tabular}{ccc}
\hline $\begin{array}{c}\text { Shearing velocity } \\
v \\
\left(\mathrm{~mm} \mathrm{~min}^{-1}\right)\end{array}$ & $\begin{array}{c}\text { Initial } \\
\text { voidratio } \\
e\end{array}$ & $\begin{array}{c}\text { Angle of internal friction } \\
\varphi \\
(\text { degree })\end{array}$ \\
\hline 0.05 & 0.465 & 25.8 \\
0.10 & 0.465 & 25.3 \\
0.20 & 0.465 & 26.9 \\
0.20 & 0.525 & 25.9 \\
0.20 & 0.566 & 25.5 \\
0.50 & 0.465 & 26.7 \\
1.00 & 0.465 & 25.2 \\
\hline
\end{tabular}

with the void ratio, while there is no obvious trend for the effect of shearing velocities on internal friction angles under the range of shearing velocities from 0.05 to $1 \mathrm{~mm} \mathrm{~min}^{-1}$.

Three shearing states at the temporary state, the peak state, and post-peak state were considered in order to investigate the friction angle at different volume change points. It should be noted that the friction angle obtained from the three shearing states is not the internal friction angle. For the temporary state, the friction angle was defined as the tested wheat was characterized by zero volume change. The peak state friction angle was determined when the peak value of deviator stress occurred. The post-peak state friction angle was obtained at the end of the test. Three friction angles corresponding to the temporary state, the peak state, and the end of the test were all estimated using the MohrCoulomb failure criterion.

In order to investigate the friction angles at the temporary state, peak state and at the end of the test for each specimen in detail, the effects of the different parameters on the friction angles are presented (Fig. 11). Among them, friction angles under the temporary state were compared with those of the peak state and the friction angles at the end of the test. Note Fig. 11b for example, for a confining pressure of $100 \mathrm{kPa}$ with a shearing velocity of $0.2 \mathrm{~mm}$ $\mathrm{min}^{-1}$, the friction angles under the temporary state are 26.3, 26.1 , and $25.0^{\circ}$, respectively. The friction angles under the peak state are $26.9,26.4$, and $25.9^{\circ}$, respectively. The friction angles of the specimens at the end of the test are 25.6, 25.4 , and $23.0^{\circ}$ with the corresponding initial void ratios of $0.465,0.525$, and 0.566 , respectively. It may be concluded from Fig. 11 that the friction angle decreases with increasing void ratio. Generally, the temporary state friction angles fall between the peak-state friction angles and the friction angles at the end of the test.

For different states during shearing, the effect of different shearing velocities on friction angles are presented (Fig. 12). It may be observed that friction angles decrease with increasing shearing velocities. The general trend of the influence of the shearing velocity on the friction angle is 


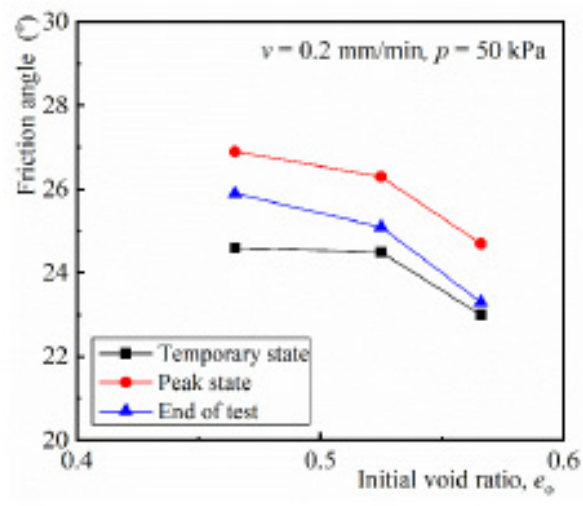

(a)

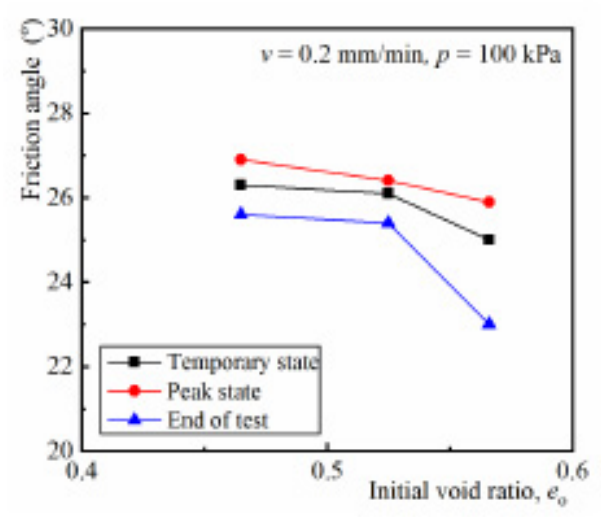

(b)

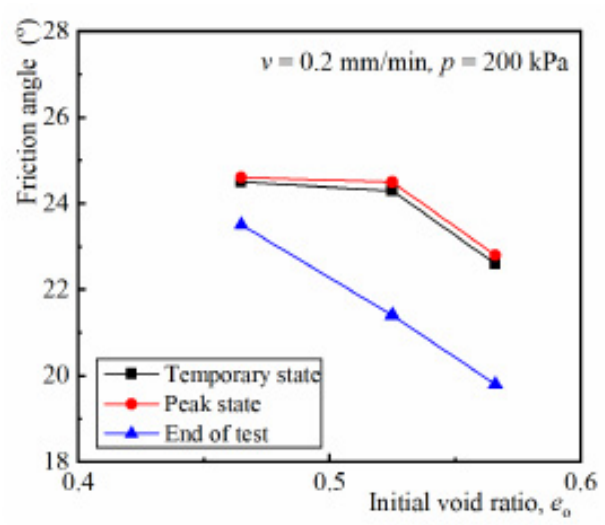

(c)

Fig. 11. Relationship between friction angles and initial void ratios under different confining pressures at $v=0.2 \mathrm{~mm} \mathrm{~min}^{-1}$.

similar to that presented in Fig. 11. The influence of confining pressure on friction angles is presented (Fig. 13). It may be concluded that the lowest friction angles occur at confining pressure $p=200 \mathrm{kPa}$ under different voids. The highest friction angles under peak state occur at confining pressure $p=100 \mathrm{kPa}$, which is different than that under temporary state and at the end of the test.

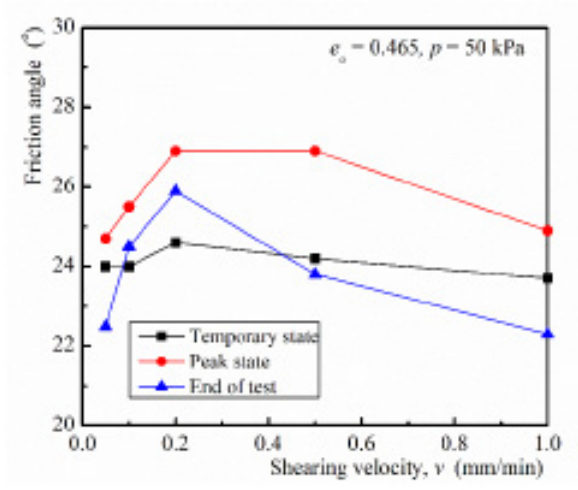

(a)

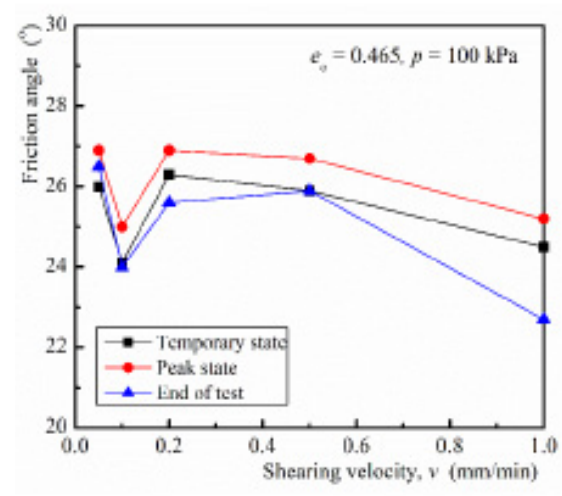

(b)

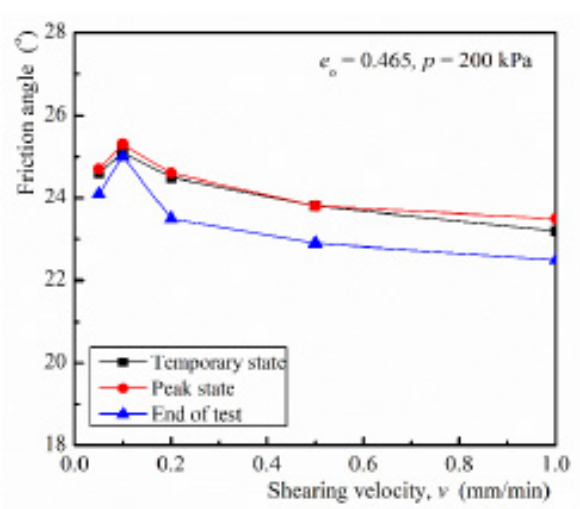

(c)

Fig. 12. Relationship between friction angles and shearing velocities under different confining pressures at $e_{\mathrm{o}}=0.465$.

The dilatancy angle $\psi$ is defined as Eq. (4) according to other researchers (Chakraborty and Saldago, 2010; Chen and Zhang, 2016):

$$
\sin \psi=\frac{-d \varepsilon_{v} / d \varepsilon_{1}}{2-d \varepsilon_{v} / d \varepsilon_{1}},
$$

where: $d \varepsilon_{v}$ represents volumetric strain increment and $d \varepsilon_{1}$ represents axial strain increment. 


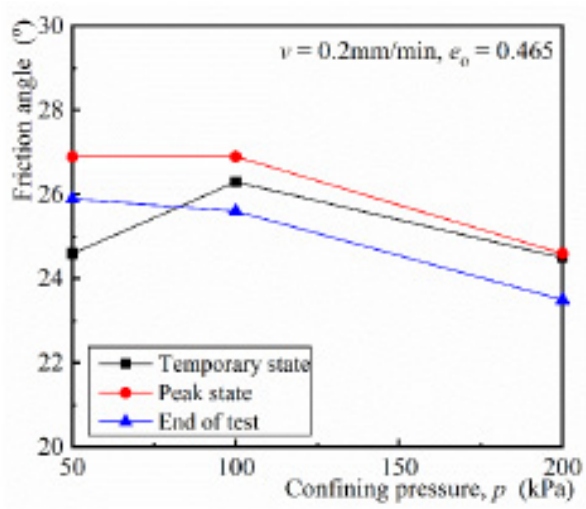

(a)

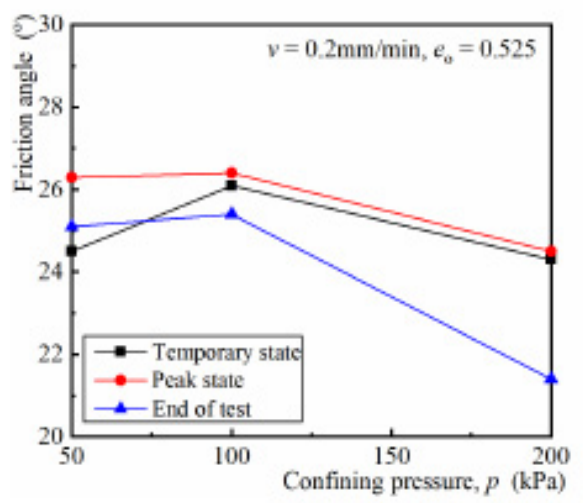

(b)

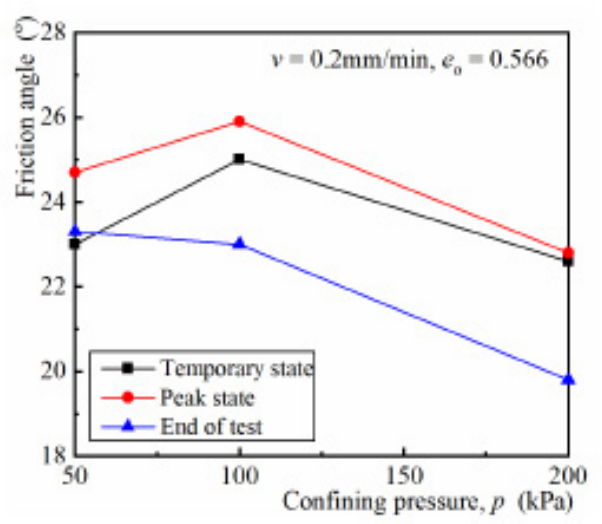

(c)

Fig. 13. Relationship between friction angles and confining pressures under different initial void ratios at $v=0.2 \mathrm{~mm} \mathrm{~min}^{-1}$.

It may be observed that the maximum dilatancy angle $\psi_{\max }$ depends on both the void ratio and the confining pressure value (Fig. 14). Higher dilatancy values are observed for denser samples. The large cell pressure diminished the dilatancy angle. In addition, the dilatancy angles are affected by the shearing velocities. There are significant differences in dilatancy angles at different shearing velocities. The experimental results indicated that dilation behaviour was suppressed due to the reinforcement of increased confining pressure. For the series of tests with an initial void

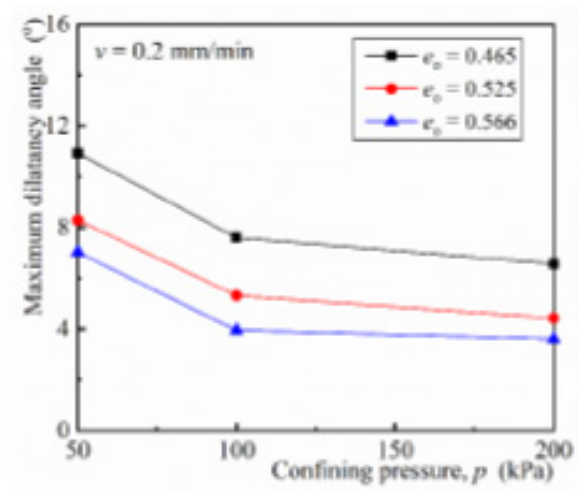

(a)

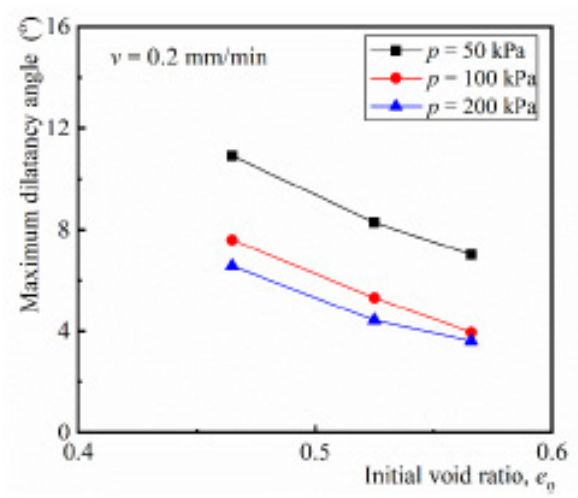

(b)

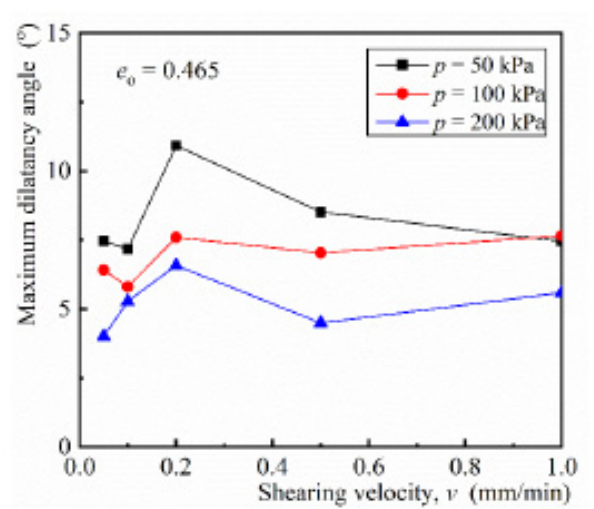

(c)

Fig. 14. Generation of maximum dilatancy angels under different states.

ratio of 0.465 and shearing velocity of $0.2 \mathrm{~mm} \mathrm{~min}^{-1}$, the dilatancy angles are $10.9,7.6$, and $6.6^{\circ}$, corresponding to confining pressures of 50,100 , and $200 \mathrm{kPa}$, respectively. For the confining pressure of $200 \mathrm{kPa}$, the dilatancy angles are $6.6,4.4$, and $3.6^{\circ}$ for the initial void ratios of 0.465 , 0.525 , and 0.566 , respectively, with a shearing velocity of $0.2 \mathrm{~mm} \mathrm{~min}^{-1}$. It may be concluded that the dilatancy angles decrease with increasing confining pressures and increasing void ratios. 
The dilatancy equation proposed by Rowe (1962) and Bolton (1986) is commonly used to describe the dilatancy character of soil. According to the Rowe theory, dilatancy can be related to internal friction in the form of Eq. (5):

$$
R=D K
$$

where: $R=\frac{\sigma_{1}^{\prime}}{\sigma_{3}^{\prime}}, D=1-\frac{d \varepsilon_{v}}{d \varepsilon_{1}}$, and $K=\tan ^{2}\left(\frac{\pi}{4}+\frac{\varphi_{f}}{2}\right)$.

In this paper, Rowe's equation was used to evaluate wheat dilatancy during shearing. The typical experimental relationship between $\frac{d \varepsilon_{v}}{d \varepsilon_{1}}$ and axial strain is plotted (Fig. 15). The zero dilative rate indicates the conversion from contraction to dilation during shearing. The dilation rate did not reach zero at the end of the test because of the limit of the apparatus displacement measurement. The calculated parameter $K$ and $\varphi_{f}$ was obtained using Eq. (5). The values of parameter $K$ are related to the axial strain (Fig. 16), which fluctuates with the axial strain especially after the peak states. The parameter $K$ for each test was

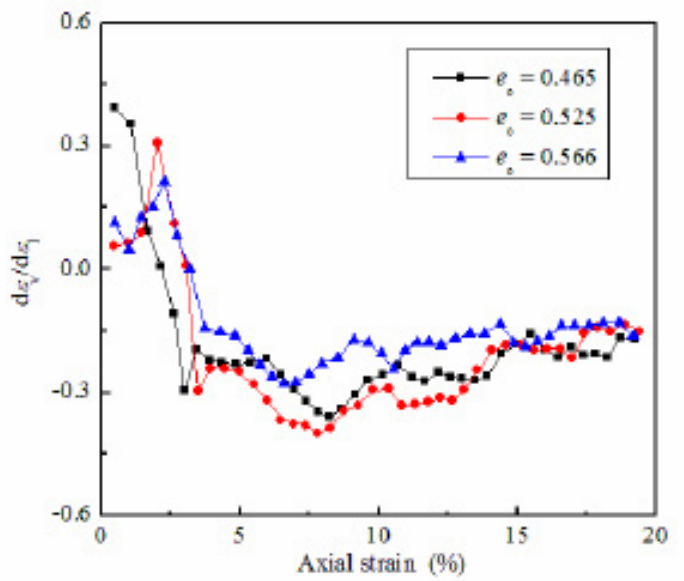

Fig. 15. Relationship between $d \varepsilon_{v} / d \varepsilon_{1}$ and axial strain of wheat for different initial void ratios $\left(p=50 \mathrm{kPa}, v=0.2 \mathrm{~mm} \mathrm{~min}^{-1}\right)$.

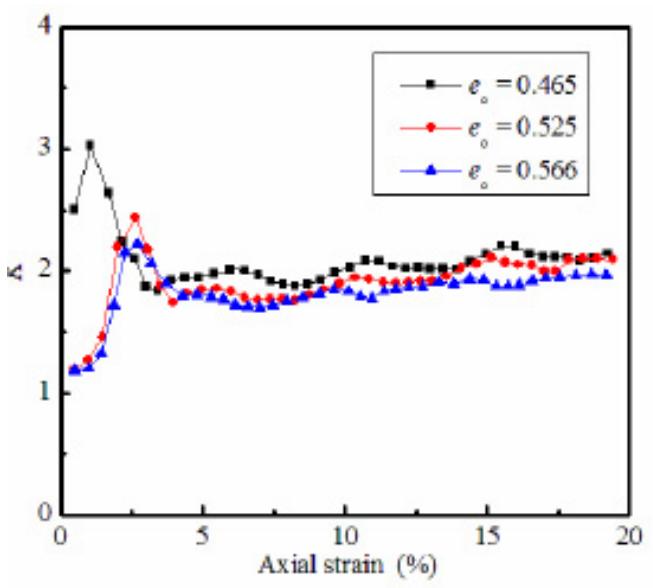

Fig. 16. Rowe's model parameter $\mathrm{K}$ of wheat for different initial void ratios $\left(p=50 \mathrm{kPa}, \boldsymbol{v}=0.2 \mathrm{~mm} \mathrm{~min}^{-1}\right)$. averaged with the fluctuant stage usually occurring after the peak states. Values of parameter $K$ ranging from 1.8 to 2.1 were calculated from all of the tests, corresponding to a friction angle $\varphi_{f}$ from 17.3 to $20.6^{\circ}$. The average value of parameter $K$ is 1.98 , which is accompanied with friction angle $\varphi_{f}=19.1^{\circ}$.

\section{CONCLUSIONS}

In this paper, a double cell triaxial system has been developed based on the traditional triaxial system, which is suitable for testing agricultural granular material. A series of tests were conducted on wheat to investigate the influence of the shearing velocity, void ratio and confining pressure on the shear strength and dilatancy characteristics of wheat granular material. The following conclusions may be drawn based on the experimental study:

1. The shearing velocities have an influence on the shear strength, internal friction angle and apparent cohesion. Also, the volumetric strain-axial strain response complied with the dilatancy angles, which are influenced by confining pressure.

2. All friction angles at three different states increase with the decreasing void ratio, resulting in a significant increase in shear strength. The dilatancy angles decrease with increasing confining pressures, which range from 3.6 to $10.9^{\circ}$.

3. The stress-dilatancy relationship based on Rowe's equation was analysed for the tested wheat. The parameter $\mathrm{K}$ is closely related to the axial strain. The value of parameter $K$ ranges from 1.8 to 2.1, corresponding to a friction angle of 17.3 to $20.6^{\circ}$ for the initial void ratio of 0.566 , 0.525 , and 0.465 , respectively.

Conflict of interest: The Authors do not declare conflict of interest.

\section{REFERENCES}

ACI 313-97, 1997. Standard practice for design and construction of concrete silos and stacking tubes for storing granular materials, American Concrete Institute, Farmington Hills, MI. https://doi.org/10.14359/3390

ASAE S352.2 APR1988 (R2017), 2017. Moisture MeasurementUnground Grain and Seeds.

Ayuga F., Aguado P., Gallego E., and Ramirez A., 2005. New steps towards the knowledge of silos behaviour. Int. Agrophysics, 19(1), 7-17.

Ayuga F., Guaita M., and Aguado P., 2001. SE-structures and environment: static and dynamic silo loads using finite element models. J. Agric. Eng. Res., 78(3), 299-308. https://doi.org/10.1006/jaer.2000.0640

Bishop A.W. and Donald I.B., 1961. The experimental study of partly saturated soil in the triaxial apparatus. Proc. 5th Int. Conf. Soil Mechanics and Foundation Engineering, Vol. 1, 13-21, July, Paris, France.

Bolton M.D., 1986. Strength and dilatancy of sands. Géotechnique, $36(1), 65-78$. 
Britton M.G. and Moysey E.B., 1986. Grain properties in the proposed new engineering practice on bin loads. ASAE Paper No. 864502. St. Joseph, MI, USA.

BS EN1991-4-2006. Eurocode 1-Actions on structures-Part 4: Silos and Tanks, European Committee for Standardization, Brussels.

Carson J.W., 2001. Silo failures: Case histories and lessons learned. Handbook of Powder Technology, 10, 153-166. https://doi.org/10.1016/s0167-3785(01)80017-8

Carson J. and Craig D., 2015. Silo design codes: Their limits and inconsistencies, 7th World Congr. Technol. (WCPT7). Procedia Eng., 102, 647-656. https://doi.org/10.1016/j.proeng.2015.01.157

Chakraborty T. and Salgado R., 2010. Dilatancy and shear strength of sand at low confining pressures. J. Geotechnical Geoenvironmental Eng., 136(3), 527-532. https://doi.org/10.1061/(asce)gt.1943-5606.0000237

Chen X. and Zhang J., 2016. Influence of relative density on dilatancy of clayey sand-fouled aggregates in large-scale triaxial tests. J. Geotechnical Geoenvironmental Eng., 142(10), 06016011. https://doi.org/10.1061/(asce)gt.1943-5606.0001542

Dogangun A., Karaca Z., Durmus A., and Sezen H., 2009. Cause of damage and failures in silo structures. J. Performance Constructed Facilities, 23(2), 65-71. https://doi.org/10.1061/(asce)0887-3828(2009)23:2(65)

Goodey R.J., Brown C.J., and Rotter J.M., 2017. Rectangular steel silos: Finite element predictions of filling wall pressures. Eng. Struct., 132, 61-69. https://doi.org/10.1016/j.engstruct.2016.11.023

GB 50077-2017. Standard for design of reinforced concrete silos. (in Chinese).

Guaita M., Couto A., and Ayuga F., 2003. Numerical simulation of wall pressure during discharge of granular material from cylindrical silos with eccentric hoppers. Biosystems engineering, 85(1), 101-109. https://doi.org/10.1016/s1537-5110(03)00037-0

Hardin B.O., Hardin K.O., Ross I.J., and Schwab C.V., 1990. Triaxial compression, simple shear, and strength of wheat en masse. Trans. ASAE 33(3): 933-943. https://doi.org/10.13031/2013.31420

Horabik J. and Molenda M., 2017. Distribution of static pressure of seed in a shallow model silo. Int. Agrophys., 31, 167-174. https://doi.org/10.1515/intag-2016-0038

Kobyłka R., Horabik J., and Molenda M., 2017. Numerical simulation of the dynamic response due to discharge initiation of the grain silo. Int. J. Solids Structures, 106-107, 27-37. https://doi.org/10.1016/j.ijsolstr.2016.12.001

Liu S.D., Zhou Z.Y., Zou R.P., Pinson D., Yu A.B., 2014. Flow characteristics and discharge rate of ellipsoidal particles in a flat bottom hopper. Powder Technol., 253, 70-79. https://doi.org/10.1016/j.powtec.2013.11.001

Moya M., Aguado P. J., and Ayuga F., 2013. Mechanical properties of some granular agricultural materials used in silo design. Int. Agrophys., 27(2), 181-193. https://doi.org/10.2478/v10247-012-0084-9

Moya M., Ayuga F., Guaita M., and Aguado P., 2002. Mechanical properties of granular agricultural materials. Transactions of the ASAE, 45(5), 1569. https://doi.org/10.13031/2013.11062
Moya M., Guaita M., Aguado P., and Ayuga F., 2006. Mechanical properties of granular agricultural materials, part 2. Transactions of the ASABE, 49(2), 479-489. https://doi.org/10.13031/2013.20403

Nielsen J., 1977. Model laws for granular media and powders with a special view to silo models. Archives of Mechanics, 29(4), 547-560.

Puri V.M., 2002. Characterizing powder flowability. Chemical Processing, 65-39.

Ramírez A., Moya M., and Ayuga F., 2009. Determination of the mechanical properties of powdered agricultural products and sugar. Particle and Particle Systems Characterization, 26(4), 220-230. https://doi.org/10.1002/ppsc.200800016

Ramírez A., Nielsen J., and Ayuga F., 2010. Pressure measurements in steel silos with eccentric hoppers. Powder Technol., 201(1), 7-20. https://doi.org/10.1016/j.powtec.2010.02.027

Rotter J.M., 2009. Silos and tanks in research and practice: state of the art and current challenges, Proc. Int. Association for Shell and Spatial Structures (IASS) Symp., Valencia Evolution and Trends in Design, Analysis and Construction of Shell and Spatial Structures. Universidad Politecnica de Valencia, Spain, 65-76. https://doi.org/10.1260/026635109789043214

Rotter J.M., Holst J.M.F.G., Ooi J.Y., and Sanad A.M., 1998. Silo pressure predictions using discrete-element and finiteelement analyses. Philosophical Transactions of the Royal Society of London. Series A: Mathematical. Physical and Eng. Sci., 356(1747), 2685-2712. https://doi.org/10.1098/rsta.1998.0293

Rowe P.W., 1962. The stress-dilatancy relation for static equilibrium of an assembly of particles in contact. Proceedings of the Royal Society of London. Series A. Mathematical and Physical Sciences, 269(1339), 500-527. https://doi.org/10.1098/rspa.1962.0193

Ruiz A., Couto A., and Aguado P.J., 2012. Design and instrumentation of a mid-size test station for measuring static and dynamic pressures in silos under different conditions-Part II: Construction and validation. Computers and electronics in agriculture, 85, 174-187. https://doi.org/10.1016/j.compag.2012.04.008

Stasiak M., Tomas J., Molenda M., Rusinek R., and Mueller P., 2010. Uniaxial compaction behaviour and elasticity of cohesive powders. Powder Technol., 203(3), 482-488. https://doi.org/10.1016/j.powtec.2010.06.010

Thompson S.A. and Ross I.J., 1983. Compressibility and frictional coefficients of wheat. Transactions of the ASAE, 26 (4), 1171-1176. https://doi.org/10.13031/2013.34099

Tripodi M.A., Puri V.M., Manbeck H.B., and Messing G.L., 1994. Triaxial testing of dry, cohensive powder and its application to a modified Cam-clay constitutive model. Powder Technol., 80 (1), 35-43. https://doi.org/10.1016/0032-5910(94)02843-5

Turner A.P., Montross M.D., McNeill S.G., Sama M.P., Casada M.E., Boac J.M., Bhadra R., Maghirang R.G., and Thompson S.A., 2016. Modeling the compressibility behavior of hard red wheat varieties. Transactions of the ASABE, 59 (3), 1029-1038.

https://doi.org/10.13031/trans.59.11432 
Wang Y., Gao Y., Guo L., and Yang Z., 2018. Influence of intermediate principal stress and principal stress direction on drained behavior of natural soft clay. Int. J. Geomechanics, 18(1), 04017128 . https://doi.org/10.1061/(asce)gm.1943-5622.0001042

Wang Y., Gao Y., Li B., Guo L., Cai Y., Mahfouz A.H., 2019. Influence of initial state and intermediate principal stress on undrained behavior of soft clay during pure principal stress rotation. Acta Geotechnica, 14(5), 1379-1401. https://doi.org/10.1007/s11440-018-0735-5

Wheeler S.J., 1988. The undrained shear strength of soils containing large gas bubbles. Géotechnique, 38(3), 399-413. https://doi.org/10.1680/geot.1988.38.3.399

Yin J.H., 2003. A double cell triaxial system for continuous measurement of volume changes of an unsaturated or saturated soil specimen in triaxial testing. Geotechnical Testing J., 26(3), 353-358. https://doi.org/10.1520/gtj11307j

Zeng C. and Wang Y., 2019a. Compressive behaviour of wheat from confined uniaxial compression tests. Int. Agrophys., 33(3): 347-354. https://doi.org/10.31545/intagr/110809
Zeng C. and Wang Y., 2019b. The shear strength and dilatancy behaviour of wheat stored in silos. Complexity, Article ID 1547616. 9 pages. https://doi.org/10.1155/2019/1547616

Zhang Q., Puri V.M., and Manbeck H.B., 1986. Determination of elastoplastic constitutive parameters for wheat en masse. Transactions of the ASABE, 29(6), 1739-1746. https://doi.org/10.13031/2013.30382

Zhang Q. and Britton M.G., 2003. A micromechanics model for predicting dynamic loads during discharge in bulk solids storage structures. Canadian Biosystems Eng., 45, 5.

Zhang S., Lin P., Wang C.L., Tian Y., Wan J.F., and Yang L., 2014. Investigating the influence of wall frictions on hopper flows. Granular Matter, 16(6), 857-866. https://doi.org/10.1007/s10035-014-0533-1

Zhao Y., Cao Q.S., and Su L., 2013. Buckling design of large circular steel silos subject to wind pressure. Thin-Walled Structures, 73, 337-349. https://doi.org/10.1016/j.tws.2013.08.015 